\title{
The Eco-space and Female Agency in Bole Butake's Lake God
}

\section{Vivian Ntemgwa Nkongmenec}

\author{
Assistant Lecturer \\ University of Douala, Cameroon
}

Doi: $10.2478 / \mathrm{mjss}-2018-0045$

\begin{abstract}
The ever-increasing environmental crises and the subsequent decay of the earth is a veritable call for concern which has stimulated man's consciousness vis-à-vis his own very existence and his natural surroundings. There is therefore, the need for continuous resistance against the socio-cultural, political and economic manoeuvres that place man and his environment at extreme ends. This paper, therefore, focuses on the study of Bole Butake's play: Lake God. It adopts both the eco-critical and eco-feminist approaches and hypothesizes that Butake's depiction of a panoply of issues that centre around the female body and the land foreshadow a quest to overcome ecological and female oppression in order to render the land a more fertile ground for sustainable development and female empowerment. The paper contends that Butake's play resonates a feminist self-consciousness which is suggestive of the need to seek alternative means of combating land exploitation in order to sustain a symbiotic relationship between man and his eco-space. In reading Butake's work from an eco-feminist perspective, this paper intends to show that the characters he creates and the milieu in which they are positioned place the woman in a precarious state. Drawing therefore, from the global tenets of eco-feminism which posit that the woman and nature are related based on their history of domination and exploitation, this paper intends to revisit the eco-space and female agency in Butake's work to postulate that the woman has the power to preserve the land and to create a healthy and conducive atmosphere. The paper, thus, exemplifies the author's admiration for one's native land which must be treasured and protected.
\end{abstract}

Keywords: Resistance, Sustainability, Eco-criticism/feminism, Self-consciousness, Female agency

\section{Introduction}

The relationship between man and his environment is a catalyst that is presumed on the view that everything in the ecological system is interconnected. The ever-increasing environmental crises and the subsequent decay of the earth is a veritable call for concern which has awaken man's consciousness vis-à-vis his own very existence and his natural surroundings. There is therefore, the need for continuous resistance against the socio-cultural, political and economic manoeuvres that place man and his environment at extreme ends. This paper, therefore, focuses on the study of Bole Butake's play: Lake God (1999) ${ }^{1}$. It adopts both the eco-critical and eco-feminist approaches and postulates that Butake's depiction of a panoply of issues that centre around the female body and the land foreshadow a quest to overcome environmental and female oppression in order to render the land a more fertile ground for sustainable development and female empowerment.

Butake's play resonates a feminist self-consciousness which is suggestive of the need to seek alternative means of combating land exploitation in order to sustain a symbiotic relationship between man and his environment. In reading Butake's works from an ecofeminist perspective, this

\footnotetext{
${ }^{1}$ Bole Butake, Lake God (1999). All references from this text shall henceforth be put in parenthesis and abbreviated as $L G$, followed by the page number.
} 
paper upholds that the characters he creates and the milieu in which they are positioned places the woman in a precarious state which speaks against her wellbeing. There is therefore, the need for persistent resistance against any undesirable socio-political and economic manoeuvres that place man and his environment at extreme ends.

In order to properly unveil the patriarchal bearings that subjugate both the woman and her natural surroundings, this paper draws from eco-criticism which has become one of the prominent and promising areas in literary studies. This is based on the fact that eco-critical ideologies represent an intervening space and a self-conscious attempt by eco-critics to seek for alternative ways of combating environmental hazards and the subsequent festering of the earth. It is in line with the literary shaping of nature that Patrick Murphy posits that literature has "brought nature onto the stage of culture as a speaking subject" $(2000$, p. 56$)$ which in turn, allow works "call on humans to perform" (Murphy,1995:24). By extension, Murphy avers that when nature occupies an important place in the field of literature, there would certainly be changes in human behavioural patterns in society. Concurring with Murphy, Caminero-Santangelo (2009, p. 699) contends that "ecocriticism aims to decentre humans, often by giving nature "back" its subjectivity." He further says that "ecocritics [must] represent nature (speak for and about it) as a subject with rights by finding (listening to) nature's voice". If man is inextricably linked to his environment, then, literary writers in their creative endeavour cannot disassociate such a context-specific bond between man and his immediate surroundings.

Eco-criticism is conceptualised on environmental representations which according to David Mazel cited by Caminero-Santangelo (2009, p. 700) "are constructions tied to power and to ignore this political component of environmental representations is to ignore one's own (interested) position within a power/knowledge matrix". Therefore, Butake's ideological thrust in his play, one may argue, centres on the symbolic correlation between man and his ecological history which has become a site of socio-political and economic upheaval but which rather reincarnates in his artistic resonance to depict the tragedy that awaits the Fon who goes against the very sacrificial rite that connects his people to their land and ancestors. Moreover, the continuous manipulation of the farmland crises exposes the strength of female power at work. The result, no doubt, is the plague that befalls the entire village because of the anger of the lake god.

\section{Eco-critical Perspectives}

It is but a truism that the whole cycle of life revolves around a specific context and man's life is shaped by the socio-cultural, political, economic and above all, ecological and cosmological structure that defines the human person. In his extensive discussion on African literature and ecocriticism, William Slaymaker cited by Caminero-Santangelo (2009, p.698) argues "that global ecocritical responses to what is happening to the earth have had an almost imperceptible African echo and calls for both African writers and critics to embrace what he sees as a global ecocritical movement". Even though Slaymaker invites both the African writer and critic to align along the path of the global eco-critical movement, Caminero-Santangelo (2009, p. 699) in his own view, expresses a kind of scepticism which is born out of the fear that the criteria Slaymaker uses to determine if a piece of writing is properly environmental come from a primarily Anglo-American ecocritical framework, associated with the application of the sciences to literature and with deep ecology, which focuses on attacking "anthropocentrism", which in itself involves "a refusal to define environmental problems in terms of effects on humans and in terms of struggles for a more just, equitable set of relationships among humans". This implies that the Anglo-American brand of ecocriticism according to Caminero-Santangelo (2009, p. 699) "rejects the nature-culture dualism which objectifies nature and places the category of culture/humanity at the center of things" and by so doing "reinforces the exploitation of the environment".

Shifting from anthropocentricism, Caminero-Santangelo proposes another facet into the reading of African literary texts which does not allow for the continuous environmental exploitation in the African context because it harnesses both eco-criticism and African environmental history. It is from the light of this argument and assumption that this paper focuses on Butake's play, in order to unravel the strength of women in the face of the ecological crises and the environmental history 
that inform the world of the play. The women's action in the world of the play reveals both the link between man's attitude towards the environment as well as the community relationship with nature. Butake, however, projects his own voice onto a silent and oppressed class in society that needs protection. It is apparent that the playwright speaks for a human/nature interrelatedness that must define and shape man's existence. The female personality and the land in this case, represent a potent mix which needs to be valorised, treasured and protected from any form of man- made and global hazard.

\section{Female Agency versus Ecological Crises}

In the play, the female characters express a conscious sense of their alliance with their immediate milieu. It is based on this awareness that they rally as a unique force to urge the Fon to send the cattle rearers away with their cattle that keep destroying their crops. The women on their part see the land as a terrain for crop cultivation and nurturing. Just as women treasure their bodies so too do they treasure their land. This explains why the Fon's inability to resolve the land issue between Dewa, the cattle rearer, and the women leads to a drastic decision whereby the women unanimously choose to deprive their husbands of both sex and food because their husbands too seem not to show any concern for them for fear of being reprimanded by the Fon, who is their traditional authority.

To show their determination and strength, the women go ahead to take an "oath of sealed lips"( $L G$, p.24) whereby they resolve to remain silent as a way of expressing their discontentment. It is Ma Kusham, one of the well respected women in the play, who administers the oath to the women, thus:

Ma Kusham: Hold the stick in your right hand between the thumb and fore-finger like this. Cross your lips vertically with the stick like this. Break it in the middle and throw both ends behind you while repeating the following: If my mouth discloses what my ears have heard in this gathering, may my tongue swell and fill my mouth with dumbness (LG, p.25).

This can be seen as a covenant that binds and determines the fate of the women in the drama. It is the tenacity, the solemnity and the serious tone of the ritual that exposes the height of female agency and their willingness to challenge and deconstruct male hegemony that has oppressed the female gender in all shapes and forms and for so long. The most disheartening part of it too, is that both the women and their corn farms are neglected by the men. Even when the women repeatedly remind their husbands to pin sticks and form a fence to protect their crops from the cattle, they all give deaf ears to their request. Although the men seem not to be bothered with the state of the farmlands, they are indirectly affected when the women take the oath. This shows that in spite of their feeling of separateness from the crops, they are inextricably intertwined with the environment. In line, therefore, with the eco-feminist view that both women and nature share the same oppression, the neglect of building fences to protect the women's corn farms by their men and the fact that the cattle not only eat but also trample on the corn which is an element of nature underscores the need to protect both women and nature. An eco-feminist Ariel Salleh, (1984, p.345) posits that women "flow with the system of nature" which implies that if anything disrupts one, it directly or indirectly affects the other.

The gap created by the exiled male Kwifon ${ }^{2}$ ( $L G$, p. 39) is occupied by the women's Fibuen ${ }^{3}$. According to Fisiy, one of the notables, the women are left with no choice than to voice out their grievances. This explains why he immediately acknowledges the importance of women in response to Forgwei's challenge to female political activism: "Who gave such powers to women? We cannot really blame the women. The Fon is the one breaking the laws and destroying the land in the name of this new religion brought by Father Leo" (LG, p. 30). The men on their part are all spellbound and it is then that they too come to the realization that not until the Fon takes a resolute decision to expel the cattle and their owners from the land, no married man is going to either have sex or eat

\footnotetext{
${ }^{2}$ The Kwifon is a secret/sacred male cult that acts as the ruling council in the play.

${ }^{3}$ The Fibuen is a secret/sacred female cult.
} 
food prepared by a woman again.

At this point then, it is understood that not even the men in the land have the possibility of questioning the Fon because of his political stamina which is well fortified by his conversion to the new religion. In a conversation between the Fon and Father Leo about the farmland crises, there is clear evidence that the two are guided by their egocentric nature and the desire to desecrate the land.

Fon: But the women want to spoil my chances, Father. If the cattle rearers are forced to leave, my chances will be lost. Development in the village will stop and the government might even revoke my first class chieftaincy.

Father Leo: There is absolutely nothing these village women can do. If we could succeed in neutralising the Kwifon, that terrible secret cult, what more of a handful of ignorant women? ... (LG, p. 37)

To show the bond between man/nature and his mythical beliefs, Shey Tanto alongside some seven most important members of the exiled Kwifon go to the sacred grove by the lake where they pour libation with the aim of invoking the spirit of the lake god to intervene in the land. In a solemn incantatory tone, Shey Tanto has this to say:

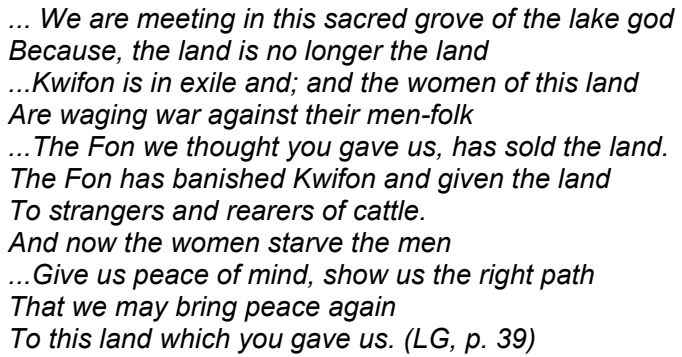

The above excerpt, lays emphasis on cultural and environmental connectivity that binds man and his ancestors. In spite of the petition from the men to the lake god, it is rather the women who take an action that permits them to envisage a new sustainable future for the society which they hope will embrace and harness both cultural and environmental perceptions. Here, Butake can be seen as a political dramatist who writes in a way that seeks to represent such political issues which are themselves sustained by his commitment to re-awaken popular appeal. The message is that both cultural and ecological preservation are equal endeavours which when unified, can create meaningful and positive objectives within the society. To Butake therefore, development means power decentralization void of egocentric tendencies which are based on the understanding that any attempt to jeopardize the future of those who constitute the working force, like the women, can lead to devastating consequences. These women are closely associated with the earth because in the absence of white collar jobs for them based on the patriarchal nature of the society where access to education is denied the woman, the land becomes their source of comfort and economic stamina and should not be tempered with.

Moreover, the men who have been disempowered by the Fon through the exile of the Kwifon equally come to the realization that the female agency is the only avenue through which they can rely on in order to experience peace in the land. This is proof of the fact that man and nature are interwoven. The men like the women are called upon at this point to fight for the protection of their eco-space because it is from the farmland that their women cultivate crops to feed their families.

Page DuBois (1988, p. 28) in her examination of the underlying difference between male and female association with the land, has averred that women's bodies are "fruitful, spontaneously generating earth and give way in time to a cultural appropriation of the body as men claim that ... [women] must plough the earth, create fields, furrow them, and plant seeds if the earth is to bear fruit". At this point the woman and the land become inseparable. It is the interrelatedness between the woman and the land that compels the men to understand that the women's nurturing ability all 
depends on their continuous association with the land. Therefore, it becomes a point of duty for the men to rally behind the women in search of an everlasting peace to reign not only in the land but also in their homes. The magnitude of the female resilience is felt through one of the men,

\begin{abstract}
Maimo: .... This last night, I was gripped by desire. My friend kept nodding and nodding like a lizard. So I called my son, Chinfon, and asked him to call his mother.... She said if I had anything to tell her, I should come over to her house because she was too tired from chasing cattle out of the farm". (LG, p. 29)
\end{abstract}

Maimo further cites another instance where he asked his wife, Kimbong about food and "she said there was no soup" ( $L G$, p. 29). The metaphorical allusion and comparison of the nodding of his manhood to the nod of a lizard reduces Maimo to a real lizard itself because no matter what happens to a lizard, it keeps nodding its head in appreciation. It is therefore, high time for the men to rise up together with the women to protect the eco-space. By starving their husbands of both food and sex, women underscore a sense of consciousness that speaks to their determination to put an end to any further oppression from either the Fon or even their husbands as the case may be. In so doing therefore, the women echo an impending blockage of the cycle of life because the crops they are fighting to protect are beneficial to all living things and if destroyed, both men and women will experience greater setbacks. According to Harold Fromm (1996, p. 82),

\begin{abstract}
... A man and a woman eat food from the earth that becomes their bodies and sperms cells and eggs.... The environment is coursing through the foetus, who is made of the substances ingested by the mother. The foetus becomes a baby who becomes a person who is comprised of the plants and animals eaten by his parents and now eaten by himself. His cells, nails, hair, skin, etc. are regularly sloughed off and replaced by newly made substance derived from earth generated plants and animals. The person dies and decomposes back to the earth to provide food for new plants and animals to feed new parents, sperms, eggs, and foetuses. There is no environment, only an ensemble of elements recycled through every existing thing. The environment does not wrap around the person for his regal contemplation: the person is the environment and the environment is the person.
\end{abstract}

It is evident from the above excerpt that the eco-space which the women so much long to guard for sustainability, symbolises an arena of fertility, growth, rejuvenation and above all an embodiment of the cycle of life. Man feeds on the plants that the land produces and as the dead plants become more manure for the land, so too does the decomposed body of man also transform into manure which all show the everlasting and unending relationship between man and nature. In fulfilling the purpose of man's creation the biblical allusion that "... [Man] you were made from soil, and you will become soil again" (Genesis 3:19) gains it credibility.

Eco-feminism calls for the understanding that both women and the land share the same canopy of oppression and domination and for them to combat this and bring about changes in their environment, they must at different points in their lives, come under one umbrella to show solidarity and look for ways to express their agency. In a situation where men fold their arms and sit, women turn to the land from where they derive satisfaction. The land is a source of strength for them. During the harvesting season, women come together as a group and this gives them the opportunity to share their experiences. As such, they garner the courage and think of strategies to use to empower themselves and alternative means to protect and control the eco-space. In the world of Lake God, female agency is activated as echoed by

Yensi: I lack words with which to express my joy. The happiness that is in my heart cannot be shown on my face. The happenings of today have shown that, in spite of what some people say, the ways of the land are alive. We must be one person to succeed in our present undertaking. We must be one woman. Some here have only recently been given into marriage. Their bellies are hot. There are others who cannot control their emotions of love and sympathy. There are still others who will easily succumb to threats and the fear of being beaten. You all know where we have built the sanctuary of the Fibuen. [...] The sanctuary is the refuge for those without a heart... (LG, p. 24). 
It is based on the women's sense of consciousness that they succeed to chart a path that will eventually lead to the defeat of the Fon. The Fibuen, once revived, acts as the collective voice of the women and supported by the men to sanction the Fon. Chandra Talpade Mohanty (1995, p. 262) has observed that:

The homogeneity of women as a group is produced not on the basis of biological essentials, but rather on the basis of secondary sociological and anthropological universals. Thus... in any given piece of feminist analysis, women are characterized as a singular group on the basis of shared oppression. What binds women together is a sociological notion, the 'sameness' of their oppression.

From the above excerpt it is understood that the strength of the women lies not so much in fighting as individuals but in coming together to better form a solid ground from which they can air their grievances. It is this group identity that speaks for women under the patriarchal system.

Consequently, in Lake God, the desires of the women to live in an eco-sphere void of land related conflict is indicative of the peaceful coexistence that is normally supposed to bind man and his immediate surroundings. Rural and urban migration after colonialism resulted in the yearning for a better settlement space for people from all ethnic groups either in cities or in villages. As for the Normads or the Fulanis, they migrated from the deserts to the grass field in search of vegetation for their cattle. Hence, the influx of migrants to the grass field for pastoral reasons accounts for the ensuing land conflict between the farmers and cattle rearers. Owing to this, there have been constant clashes on land issues. The privatization of land with the highest authority in the hands of the government for developmental projects has also led to serious land crises within the postcolonial society. So many communities have witnessed the seizure and destruction of their lands by the powers that be. All these result in deforestation leading to the extinction of animals and the destruction of flora and fauna. Once this happens, man experiences untold famine which leads to malnutrition that further aggravates poverty. In the world of Butake's play, one of the characters,

Nkfusai says: All the women who have farms in Ngangba will starve this year. Dewa's cattle have ruined all the corn. The Fon knows the harvest is very near (LG, p. 15).

Her words echo the mass destruction of the crops by the cattle and so the women, men and even children will all starve because there is certainly going to be no harvest. Indeed, the Fon has sold the land to the cattle rearers for egocentric reasons and financial enrichment. Juliana Makuchi Nfah-Abbenyi (2009, p. 708) has observed that within the post-colonial society,

"...African women's roles (and sometimes men's roles) which are often linked to the land, have seen drastic changes following the movement from colonialism, through independence, to the postcolonial era that have (re)shaped African societies, histories and cultures.....women's lives have tended to be most affected by these local and global shifts."

Conscious, therefore of their vulnerable position in the face of both local and global shifts, the women are left with no other option than to seek for alternative means to combat and free themselves from the shackles of globalization which continue to threaten their source of livelihood.

In the play, there is the consistent emphasis on gender parity between the Fon as the custodian of the land and the women. According to eco-feminist tenets, men focus on their masculine rights while women dwell on their feminine roles and responsibilities. This explains why Dewa, the cattle owner, and the Fon are both interested in postulating their rights of property ownership of both the cattle and the land while the women only long to cultivate crops that will eventually feed humanity whom they see as part of their responsibility. To show how eco-conscious the women have become, they unanimously turn down the money proposed to them by the Fon as a form of compensation for their crops that have been destroyed by the cattle. The women's action equally foregrounds their sense of strength and an imaginative strategy conceptualized on their conviction that women and land and all what the land produces are inextricably linked and that the victimization of one directly affects the growth of the other. Pitting the woman against land and crop destruction, Butake draws the reader's attention to the disintegrated nature of both the female body 
and the ecosystem if both are not well protected and conserved.

\section{Eco-feminist Predictions / Ecological Preservation}

A critical observation of the role played by women in Lake God can best be described as a means through which the playwright celebrates the sense of women's consciousness within the twenty-first century to seek for alternative ways to combat environmental hazards for the sake of ecological preservation. Eco-feminists' agenda that propagates the interconnectedness between nature and the underprivileged members of the society is a crusade that cannot not be overlooked because the ecosystem, like women as the less privileged members of the society, risks being totally trampled upon if not well protected.

Eco-feminist predictions are at the centre of discussion here because women see themselves as an endangered species in the universe and therefore, seek for ways to challenge anything that stands along their path of existence. This explains why eco-feminists like Janis Birkeland (1993), Lori Gruen (1993) as well as Carolyn Merchant (1980) all share a common view though expressed in different ways that there is a firm interconnectedness between nature and women. In their different critical lenses they all come to a point of convergence that man's attitude towards the environment is that of the sole proprietor who designs all sorts of strategies and monumental structures that are as exploitative and possessive in the same way as they oppress and express their male power and authority over the women. Relating the views upheld by the foregoing ecofeminists critics to the current global environmental crises, it is but logical to affirm here that the present century is faced with extreme ecological challenges which stem both from globalization and man's quest to amass wealth even at the detriment of his own health. This is quite glaring within post-colonial African societies where it can be observed that man's avaricious nature has blinded him to the point where cultural beliefs no longer guide Africans' perception of the cosmic forces around them. It is in this regard that Kashim Ibrahim Tala et al. (2014, p. 15) aver that "one cannot reasonably attribute all post-colonial tensions to colonial encounter.... Social and cultural changes operate through individuals, and consequently, raise the problem of choice." What Tala intimates here is that individuals have the possibility to decide their fate in society. Like the case of the Fon in Lake God, he is quite aware of the impending doom that will befall his people if he does not perform the sacrifice to the lake god as custom demands but he, out of his personal egocentric nature, fails to respect his ancestral duties. This leads to his death as well as to the plaque that befalls the land. The lake which is supposed to be well catered for both spiritually and physically is neglected. As a result, the lake becomes a source of danger to the people.

The women are so much concerned with the preservation of the eco-space because they are quite aware that anything that disrupts or threatens the environment will directly affect them in a serious way. First and foremost, the women are those who bear children and once there is any disaster in the land both the men and children whom they suffer to give birth to will all perish alongside themselves as women. It is in this light that the preservation and protection of man's immediate surroundings is the women's direct cause for concern. The women no doubt, opt for any measure to protect the land and in this wise, validate Janis Birkeland's view $(1993$, p. 13) as follows:

Radical Green philosophy is premised on the conviction that the sources of the environmental crises are deeply rooted in modern culture, and therefore fundamental social transformation is necessary if we are going to preserve life on earth in any meaningful sense.

The modern culture which Birkeland refers to is palpable to the materialistic and egoistic culture of power that both the Fon and Father Leo exercise on the women in Lake God when they table their farmland crises to the Fon. Father Leo in his own hypocritical nature claims that he wants to carry out agriculture on a large scale while the Fon who pretentiously has cattle as well wants his animals to continue to graze on the land and yield more money for him. Hence the clash of personal interests and materialism that eventually leads to the Fon's demise.

Within the framework of eco-feminism, there is a clear demonstration of the connection 
between the female being and nature about which Rosemary Radford Ruether (1975, p. 204) emphasises that

Women must see that there can be no liberation for them and no solution to the ecological crises within a society whose fundamental model of relationships continues to be the one of domination. Women's movement must write their demands with those of the ecological movement to envision a radical reshaping of the basic socio-economic relations and the underlying values of this modern industrial society.

Building on Ruether's view, women are encouraged to continue to reassert their desire and determination to combat both female and ecological domination and destruction given that as women, their status also depends on their stability with the earth. It should be noted that Butake's women are all rural women and by virtue of this, their closeness to the land and all other ecological species is quite evident. Eco-feminist predictions stem from the very preconception that rural women's lives from birth are anchored on their immediate environment because they understand the dynamics and usefulness of their surroundings. In trying to protect their crops, the women in the play also open up other avenues through which the woman's beauty can always be appreciated. The beauty of a woman is most often described based on elements of nature such as plants, flowers, and even cosmic elements like the stars, the moon and even the sun. Therefore both women and nature are aesthetically bound. As sisters who share the same nature of oppression, the woman as the living being has as duty to protect her inanimate sister, (the plants). The green plants around beautify the environment but once destroyed the earth becomes barren which by extension represents the trauma which women go through in the hands of abusive men who consider women as inferior beings.

In the world of Lake God, both the woman and the land are looked upon by some male folk as commodities that can be easily bought or sold to the highest bidder. One of the causes of the land dispute between the women and Dewa, the cattle rearer, is engineered by the government whom Dewa claims "gave him" the land for grazing. Given the corrupt nature of the society, it is understood that money changed hands in one way or the other, reason why Dewa is so confident of himself when addressing the Fon in the midst of the angry women whose crops have been destroyed by Dewa's cattle. Moreover, the thingification of woman is also well spelt out in the play. This is clearly highlighted through the conversation between Lagham, a palm-wine tapper and his friend Forgwei as they comment on female power that has shocked all of the men.

Forgwei: You too, Lagham? You mean the women have decided to starve us their men?

Lagham: How can a man use his wealth to buy trouble for himself? This morning I called Mom,

that rat whom, I recently bought with my money. (LG, p. 27)

From the above conversation, the need for women to out-rightly contest for their rights and for the preservation of the eco-space becomes very imperative. The metaphorical reference to Mom as a "rat" by Lagham can be likened to the height of both female and ecological oppression which ecofeminists all seek to address and redress. According to the man, a rat has no place in the society and so too with Mom (the woman). But on the contrary, the woman has understood that both she and the rat share the same nature of oppression and their place in the society must be acknowledged. Rats live either in the bush or seek for shelter and food in the house and are a source of meat and protein to human beings as well as a source of income depending on the people's culture and beliefs. Therefore, the protection of rats and the preservation of the farms or bushes which is their habitat is a call for concern for eco-feminists and eco-critics alike. By comparing the woman to a rat, the man shows a lack in what Scott Lovic (1992, p. 169) calls the "power of awareness" which is further sustained by Barry Commoner's (1971, p. 108) first law of ecology which posits that "everything is connected to everything else". Therefore, the woman and the rat are both important within the ecosphere and should be protected. 


\section{Conclusion}

The paper set out to show that the inextricable link between nature and the woman in particular, as expounded in Butake's Lake God is a bond that shares the same level of oppression and exploitation. In this regard, both the ecocritical and eco-feminist approaches were used to enhance a better critical reading of the play with the aim of highlighting the strength of the woman and the level of consciousness that she has attained in her attempt to challenge patriarchal misgivings associated to her body and environmental manoeuvre.

A close reading of the play has revealed that in order to rectify the ills of patriarchy, the women folk have to take matters into their hands. It is the women's incessant quest to protect their farmlands that exposes their prowess and the determination to use the Fibuen to question the Fon's unruly nature in the Fondom. The destruction brought about by the Fon and Dewa is nothing compared to the female agency that evokes the issue of environmental crises that shall hopefully be restored by the innocent Boy in the play, whose mind is incorrupt. The air of hope that reigns at the end of the play reassures one that all is not lost. Shey Bo-Nyo, one of the notables hands over to Boy, who represents the future, the staff of the Kwifon to "guard it well" (LG, p. 58). This represents the symbiotic relationship between nature and culture. He will have to work with all and sundry to ensure a sustainable environment void of farmland crises and by extension, create a resounding atmosphere for female empowerment and eco-space protection and preservation.

Through a keen analysis of the eco-space and female agency in Butake's Lake God it becomes evident that the women are self-conscious and have the power to preserve the land and to create a healthy and conducive milieu for a sustainable society, even against the backdrop of patriarchal misgivings. By extension, therefore, the playwright's vision which is conceptualised on a socio-cultural and political tone, exemplifies his admiration for his native land which must be treasured and protected.

\section{References}

Birkeland, J. (1993). Ecofeminism: Linking Theory and Practice. In Greta Gaard (Ed.), Ecofeminism: Women, Animal s and Nature. Philadelphia: Temple University Press.13-59.

Butake, B. (1999). Lake God. Yaoundé: Editions CLE.

Caminero-Santangelo. B. (2009). Different Shades of Green: Ecocriticism and African Literature. In Olaniyan Tejumola and Ato Quayson (Eds.), African Literature: An Anthology of Criticism and Theory. USA: Blackwell Publishing Ltd. 698-706.

Commoner, B. (1971). The Closing Circle: Nature, Man and Technology. New York: Knopf.

DuBois, P. (1988). Sowing the Body: Psychoanalysis and Ancient Representations of Woman. Chicago, University of Chicago Press.

Fromm, H. (1996). Ecocriticism's Bang: A Review of Practical Ecocriticism: Literature, Biology and the Environment. In The Ecocriticism Reader: Landmarks in Literature Ecology, Anthens, Georgia, The University of Georgia Press.

Good News Bible. (1994). 2nd Edition. np.: The United Bible Societies.

Gruen, L. (1993). Dismantling Oppression: An analysis of the Connection between Women and Animals. In Greta Gaard (Ed.), Ecofeminism: Women, Animals and Nature. Philadelphia: Temple University Press. 60-91.

Lovic, S. (1992). Seeking Awareness in American Nature Writing. Salt Lake City: University of Utah Press.

Merchant, C. (1980). The Death of Nature: Women, Ecology and the Scientific Revolution. New York: Harper Collins.

Mohanty, C. T. (1995). Under Western Eyes: Feminist Scholarship and Colonial Discourses. In Bill Ashcroft et al (Eds.), The Post-Colonial Studies Reader (p. 262). London: Routledge.

Murphy, P. (1995). Literature, Nature and Other: Ecofeminist Critiques. New York: State of New York Press.

Murphy, P. (2000). Farther Afield in Nature-Oriented Literature. Charlottesville \& London: University of Virginia. Kiiode.

Nfah-Abbenyi, J. M. (2009). Ecological Postcolonialism in African Women's Literature. In Olaniyan Tejumola and Ato Quayson (Eds.), African Literature: An Anthology of Criticism and Theory. USA: Blackwell Publishing Ltd. 707-714.

Reuther, R. R. (1975). New Woman/New Earth: Sexist Ideologies and Human Liberation. New York: Seabury Press. 
Salleh, A. (1984). Deeper Than Deep Ecology: The Eco-Feminist Connection. Environmental Ethics 6 (Winter): 339-345.

Slaymaker, W. (2009). Echoing the Other(s): The Call of Global Green and Black African Responses. In Olaniyan Tejumola and Ato Quayson (Eds.), African Literature: An Anthology of Criticism and Theory. USA: Blackwell Publishing Ltd. 683-697.

Tala Kashim Ibrahim and Oscar C. Labang and Hans Fonka. (2014). (Eds.) Literature and Language: Interdisciplinary Perspectives. Raytown (MO): Ken Scholars Publishing. 